\title{
Seasonal Variation in the Diet of Himalayan Grey Langur (Semnopithecus ajax) in Machiara National Park, Azad Jammu and Kashmir, Pakistan
}

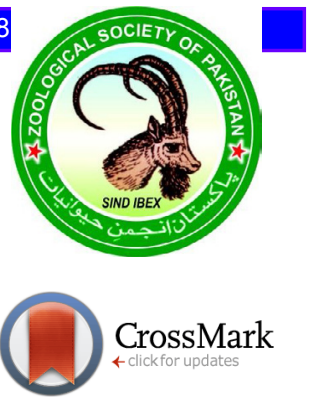

Fiza Asif ${ }^{1, *}$, Muhammad Siddique Awan ${ }^{1}$, Nasra Ashraf ${ }^{1}$, Nuzhat Shafi ${ }^{1}$, Abdul Rauf ${ }^{1}$, Khizra Bano ${ }^{1}$, Muhammad Razzaq ${ }^{2}$ and Naeem Iftikhar Dar ${ }^{2}$

${ }^{1}$ Department of Zoology, University of Azad Jammu and Kashmir, Muzaffarabad

${ }^{2}$ Department of Wildlife and Fisheries, Azad Jammu and Kashmir, Muzaffarabad

\begin{abstract}
A B S T R A C T
Kashmir grey langur (Semnopithecus ajax) (the langur) belongs to family Cercopithecidae and order Primates. Understanding food habits of wild mammals is of great importance to ecology and wildlife management. Present study was designed to determine the diet composition of Kashmir grey langur in Machiara National Park, Azad Jammu and Kashmir, Pakistan during summer 2015 and winter 2015-16 from fecal material using microhistological technique. Sixty fecal samples were collected from the study area during summer 2015 and winter 2015-16, i.e. thirty samples during each season. These samples were analyzed for the determination of food composition using microhistological technique. A total of 23 plant species were observed during summer and 15 plant species during winter season. During both the seasons Indian or Himalayan Chestnut Aesculus indica was found as the dominant plant species in the diet having relative importance value (RIV) 8.36 and 10.92 in summer and winter, respectively. Diet breadth of all the plant species was also calculated using Levin's measure of niche breadth (B). Grand viburnum Vibernum foetens showed the greatest value of diet breadth (23.52) during summer season, while during winter season wild Himalayan pear Pyrus pashia showed the greatest value of diet breadth (16.02). Future management of the National Park would require protection of core habitat of the langur in MNP. Wildlife managers should focus on conservation and increasing the number of preferred forage species of Kashmir grey langur i.e. Asculus indica, Cedrus deodara, Vibernum foetens, Pyrus pashia and Eleagnus orientalis in MNP.
\end{abstract}

Article Information
Received 14 April 2018
Revised 28 July 2018
Accepted 13 February 2019
Available online 19 September 2019
Authors' Contribution
FA compiled and collected the data
and wrote the manuscript with the
help of NA, AR and NS. MSA designed
and supervised the study. KB helped
in data collection. MR and NID helped
in field work.
Key words
Diet composition, Gray langur,
Microhistological technique, Machiara
National Park, Microphotographs.

\section{INTRODUCTION}

G rey langur or hanuman langur is the most widespread langur of the Indian Subcontinent (Nepal, China, India, Bhutan, Pakistan and Bangladesh); starting from north India in Kashmir and Himalayas in Nepal, Tibet, Bhutan, and south to Sri Lanka, west to the Indus valley in Pakistan and east to Bangladesh (Groves, 2001; Brandon, 2004), are a group of Old World monkeys constituting the entirety of the genus Semnopithecus. All taxa have traditionally been placed in the single species Semnopithecus entellus. In 2001, it was recommended that several distinctive former subspecies should be given species status, so that seven species are recognized. A taxonomic classification with fewer species has also been proposed. Genetic evidence suggests that the Nilgiri langur and purple-faced langur, which usually are placed in the

\footnotetext{
* Corresponding author: fizaasif830@gmail.com 0030-9923/2019/0006-2353\$ 9.00/0

Copyright 2019 Zoological Society of Pakistan
}

genus Trachypithecus, actually belong in Semnopithecus (https://en.wikipedia.org/wiki/Gray_langur, downloaded on 25.11. 2018). Among the seven species of grey langur Kashmir Semnopithecus ajax (the langur) is found among the Himalayan region of Pakistan and Northern India (Groves, 2001). In Pakistan, this langur is limited to district Mansehra, Pallas Kohistan, and Azad Jammu and Kashmir (AJ\&K) (Roberts, 1997). In AJ\&K, this langur is limited to the districts of Leepa Valley, Neelum Valley, Hillan game reserve and Phalla game reserve in Ditrict Bagh (Ahmed et al., 1999; Baig, 2004; Dar, 2006).

According to IUCN red list of threatened species this species is considered as "Endangered" (IUCN, 2012). An invading human expansion in the habitat of langur is the reason of langurs to be endangered (Nowak, 1999). This monkey was very rare in Pakistan, and its total population was assessed to be below 200 individuals excluding AJ\&K (Roberts, 1997). In AJ\&K its population is above 500 individuals. In Machiara National Park, langur mostly live in deciduous tree patches mixed with the moist temperate coniferous forests (Minhas et al., 2012). 
Primates respond to variations in seasonal resource abundance by changing their diet composition with alternative plant species (Remis, 1997), by increasing feeding time (Overdorff, 1996) and changing pattern of other activities like rest, travel etc. (Chapman, 1988). The physiological status such as reproduction and lactation, and sex category of an animal also influence its food selection and feeding behaviour (Altmann, 1980). Furthermore, the characteristics of habitat, including its eco-climatic conditions, exert a profound influence on all aspects of feeding ecology (Wiens, 1989).

As a herbivorous primate, Kashmir grey langur plays an immense role in the food chain. Most of the primates live in the forests where they play a fundamental role in the ecology of their habitat. They not only help the forest by being pollinators, seed predators and seed dispersers but also contribute in the cultural aspects of many countries in the world (Rajpurohit, 2005).

The langurs are ecologically very adaptable to different habitats, including tropical rain forests and quite dry savannah. They occur between $2200-4000 \mathrm{~m}$ above sea level in the subtropical, scrublands, alpine, broadleaved, coniferous, tropical and moist temperate forests (Hilton, 2000; Roberts, 1997; Nowak, 1999). They are diurnal and arboreal species and like to jump from one tree to the other from the branches when taking food. Some can adapt to living near the human settlements (Tritsch, 2001).

From the conservation point of view in Pakistan, Kashmir grey langur is very important, because its population is confined to a very small area and is constantly decreasing all over the region. There was no previous work regarding food habit analysis of grey langur using microhistological technique. The study of food habits of this langur in Machiara National Park will be a useful contribution to the scientific literature and for future management of the National Park.

\section{MATERIALS AND METHODS}

\section{Study area}

Machiara National Park (MNP) is part of the Great Himalayan chain that branches off from Nanga Parbat (Negi, 1983; Qamar, 1996). Machiara Forest was declared a Game Reserve in 1982, a Wildlife Sanctuary in 1984 and a National Park in 1996 (GoAJK, 2005; Qamar and Minhas, 2006). Machiara National Park lies at $34^{\circ}-31^{\prime} \mathrm{N}$ latitude and $73^{\circ}-37^{\prime} \mathrm{E}$ longitude between 2,000 to 4,700 m elevation, covering an area of 13,532 ha. The NP lies in the moist temperate area having deep snow and cold winters. The mean annual rainfall is $1526.7 \mathrm{~mm}$ (Baig, 2004; Hassan, 2004; GoAJK, 2005). Meteorological data nearby Muzaffarabad (35 km southwest of MNP) showed that summers were hot (average maximum air temperature $30^{\circ}-35^{\circ} \mathrm{C}$ ) and winters were cold (average maximum and minimum air temperatures approx. $15^{\circ} \mathrm{C}$ and $0^{\circ} \mathrm{C}$, respectively) (GoAJK, 2005).

\section{Sample collection and analysis}

Pellet groups of Kashmir grey langur were collected during summer (May to August 2015) and winter (November to March 2015-16), identified on the basis of pellet shape, dimensions, and structure (Edwards, 1991). Samples were collected opportunistically from habitat of the langur as fresh as possible. All pellet groups were double-bagged, labeled with information on collector, collecting time, place and conditions. The reference plant specimens were also collected from the study area. The same method of sample collection was used during both the seasons. The samples were ground, sieved and slides were prepared using the method described by Sparks and Malechek (1968) and Fjellstad and Steinheim (1996). Plant species found in faecal samples were identified after a detailed comparison of all cell characteristics with the reference collection using microhistological technique.

In the laboratory plant samples were crushed with mortar and pestle. The ground material was passed through the cotton cloth for the removal of large unrecognizable dust and other particles. Then plant samples were again ground using Virtis Homogenizer after addition of small amount of water. The ground material was transferred to a petri dish, 30\% sodium hypochlorite was added and put for $30 \mathrm{~min}$. Sodium hypochlorite was removed by using cotton cloth and the material was soaked in $50 \%$ acetic solution and left for two days. This material was put on a microscopic glass slide and evenly spread. DPX Mounting medium was added to the material and covered with a cover slip. For the preparation of faecal material slides similar procedure was adopted (Alipayo et al., 1992).

The relative frequency of a plant species identified in the fecal samples was calculated and expressed as the relative importance value (RIV), which is the total number of fragments identified for a given food species divided by the total number of all counts made in the sample and expressed as a percentage (Jnawali, 1995).

Diet breadth, representing diet diversity per fecal sample, was calculated using Levin's measure of niche breadth (B), based on the following formula (Prins et al., 2006):

$$
\mathrm{B}=1 / \sum p i^{2}
$$

Where, $\mathrm{Pi}$ is $\%$ of total sample belonging to species $\mathrm{i}(\mathrm{i}=1$, $2, \ldots ., \mathrm{n})$.

Other than using microhistological technique some observations were also made regarding, eating of plant parts other than leaves such as fruits, bark etc. 


\section{RESULTS}

\section{Diet composition}

Sixty fecal samples collected from the study area, 30 each during summer and winter season were analyzed. Twenty three plant species were identified in the diet of langur during summer 2015 and 15 plant species during winter 2015-16.

In summer Indian horse chestnut Aesculus indica $(\mathrm{RIV}=8.36)$ was the most eaten plant in the diet followed by Deodar Cedrus deodara (RIV = 7.13) (Table I).

During winter, 15 plant species were recorded from fecal samples. Among these, Banakkhor $(\mathrm{RIV}=10.92)$ was the most eaten plant followed by Blue pine Pinus wallichiana $(\mathrm{RIV}=9.30)$, Vibernum foetens $(\mathrm{RIV}=7.24)$ and Deodar $(\mathrm{RIV}=7.24)$, Russian olive Eleagnus orientalis (RIV=7.11) (Table I). The reason of utilizing fewer plant species during winter as compared to the summer may be that leaves of most of the deciduous plant species are shed during winter season. Plant leaves were the most utilized part of the plant. Student T test was used to compare the results of two seasons. Comparison of relative importance values of food items between two seasons revealed a significant difference in diet composition of Kashmir grey langur $(\mathrm{t}=4.894 ; \mathrm{p}=0.00013<0.05)$.

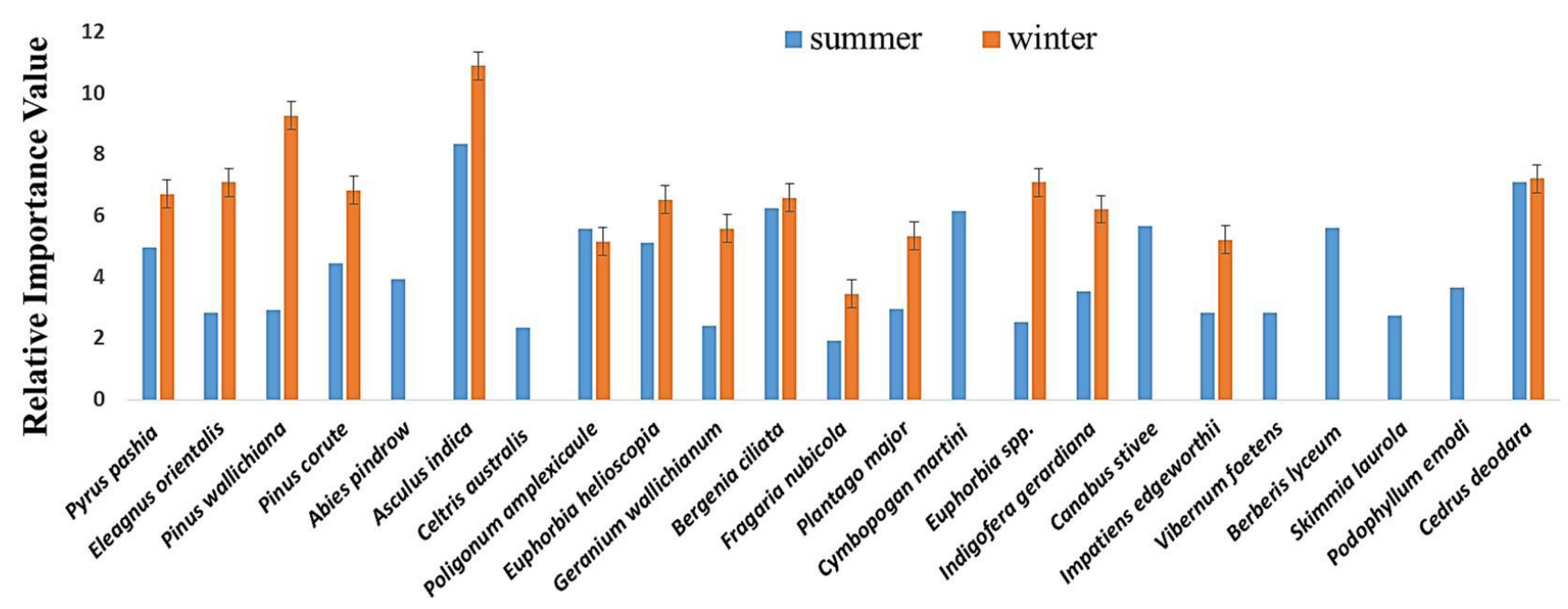

Plant species

Fig. 1. Relative importance values of plant species found in fecal samples of Kashmir grey langur during summer 2015 and winter 2015-16.

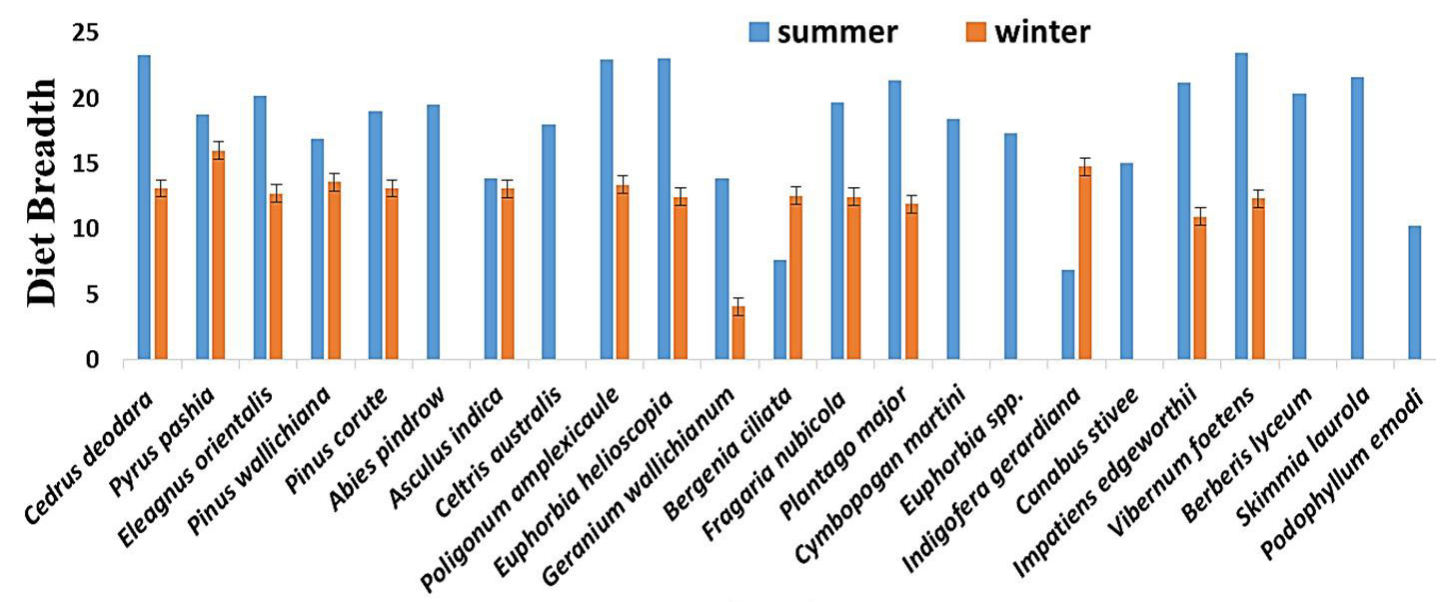

Plant Species

Fig. 2. Diet breadth values of plant species found in fecal samples of Kashmir grey langur. 
Table I.- Relative importance values (RIV) of plant species found in fecal samples of gray langur during 2015.

\begin{tabular}{|c|c|c|c|c|c|c|}
\hline \multirow{2}{*}{$\begin{array}{l}\text { S. } \\
\text { No. }\end{array}$} & \multirow[t]{2}{*}{ Scientific name } & \multirow[t]{2}{*}{ Local name } & \multicolumn{2}{|c|}{ RIV /SD } & \multicolumn{2}{|c|}{ Diet Breadth } \\
\hline & & & Summer & Winter & Summer & Winter \\
\hline 1 & Aesculus indica & Banakkhor & $8.36 / 4.13$ & $10.92 / 4.62$ & 19.49 & 0 \\
\hline 2 & Cedrus deodara & Deodar & $7.13 / 2.75$ & $7.24 / 2.52$ & 23.36 & 13.12 \\
\hline 3 & Bergenia ciliata & Betpeva & $6.27 / 3.04$ & $6.61 / 3.03$ & 7.67 & 12.54 \\
\hline 4 & Cymbopogan martini & Gogoon & $6.19 / 5.36$ & 0 & 18.45 & 0 \\
\hline 5 & Canabus sativa & Bhung & $5.68 / 3.28$ & 0 & 15.03 & 0 \\
\hline 6 & Podophyllum emodi & Ban khakhri & $5.67 / 3.79$ & 0 & 10.27 & 0 \\
\hline 7 & Vibernum foetens & Goucch & $5.62 / 3.54$ & $7.24 / 3.19$ & 23.52 & 12.33 \\
\hline 8 & Polygonum amplexicaule & Masloon & $5.59 / 2.77$ & $5.18 / 2.46$ & 22.98 & 13.41 \\
\hline 9 & Euphorbia helioscopia & Doodhal & $5.13 / 2.49$ & $6.55 / 2.05$ & 23.04 & 12.45 \\
\hline 10 & Pyrus pashia & Btangi & $4.99 / 2.93$ & $6.74 / 2.83$ & 18.79 & 16.02 \\
\hline 11 & Pinus corute & Pertth & $4.48 / 3.37$ & $6.86 / 2.84$ & 19.04 & 13.12 \\
\hline 12 & Abies pindrow & Reorh & $3.96 / 3.21$ & 0 & 19.49 & 0 \\
\hline 13 & Skimmia laurola & Neera & $3.68 / 2.19$ & 0 & 21.64 & 0 \\
\hline 14 & Indigofera gerardiana & Kainthi & $3.56 / 2.93$ & $6.24 / 3.11$ & 6.88 & 14.78 \\
\hline 15 & Plantago major & Chamchi Patter & $2.99 / 2.18$ & $5.36 / 2.98$ & 21.36 & 11.93 \\
\hline 16 & Pinus wallichiana & Kile & $2.96 / 3.08$ & $9.30 / 3.32$ & 16.89 & 13.62 \\
\hline 17 & Eleagnus orientalis & Kankoli & $2.85 / 1.55$ & $7.11 / 2.68$ & 20.16 & 12.73 \\
\hline 18 & Impatiens edgeworthii & Bun till & $2.85 / 2.09$ & $5.24 / 3.28$ & 21.18 & 10.94 \\
\hline 19 & Berberis lyceum & Sumbloo & $2.76 / 1.97$ & 0 & 20.40 & 0 \\
\hline 20 & Euphorbia spp. & Hervi & $2.56 / 2.29$ & 0 & 17.36 & 0 \\
\hline 21 & Geranium wallichianum & Rattan jog & $2.42 / 2.73$ & $5.61 / 2.25$ & 13.90 & 4.08 \\
\hline 22 & Celtris australis & Butkhrrel & $2.36 / 2.20$ & 0 & 17.98 & 0 \\
\hline 23 & Fragaria nubicola & Maiva & $1.94 / 1.06$ & $3.47 / 1.88$ & 19.72 & 12.45 \\
\hline
\end{tabular}

During summer 2015, diet breadth of Deodar was the maximum (23.36), followed by wild pear (18.79). During winter 2015, diet breadth of Deodar was the maximum (13.12) followed by wild pear (16.02) (Table I). Comparison of food items between two seasons revealed a significant difference in diet breadth of Kashmir grey langur $(\mathrm{t}=6.131403 ; \mathrm{p}=0.00001<0.05)$.

Fruit of Ban akhor was also consumed by the langur. Fruits were found from the fecal collection sites of the langur (7-8 eight fruits at each site). The langurs were seen feeding upon its bark and leaf buds as well.

\section{DISCUSSION}

Based on their diet records and natural history of mammals, they can be classified into omnivorous, herbivorous and carnivorous groups (Chen et al., 2018). Information about food habits is an important component of an animal's life history and knowledge on diet composition and selection is a fundamental element to understand many aspects of primate ecology (Bhattacharya et al., 2012). Himalayan grey langur are chiefly folivorous; also ingest flowers, seeds, cultivated crops, fruits, with high amount of toxins, like strychnine and unpleasant flora usually not eaten by other animals (Minhas et al., 2010).

Feeding habits of mammals are in the centre of interest of population biology (Lode, 1996) and ecology (Matrai et al., 1998). Many a methods have already been evolved and used to investigate dietary composition (Smith and Shandruk, 1979; Holechek et al., 1982; Shrestha and Wegge, 2006).

Primates specialize in eating leaves. Mature leaves contain a high proportion of hard-to-digest cellulose, less energy than other types of foods, and often toxic compounds. For this reason, folivorous animals tend to have long digestive tracts and slow metabolisms. Leaves were found to be the most eaten part of a plant. This is supported by a previous study conducted by Minhas et al. (2010) in Machiara National Park, reporting that langur chose leaves as compared to other plant parts.

In the present study Aesculus indica was the most eaten plant species found in fecal samples with relative importance value of 8.36 and 10.92 during summer and winter, respectively. This statement is supported by the earlier study conducted by Minhas et al. (2010) reporting that the Aesculus indica constituted major portion of the 
diet of langur. Bergenia ciliata and Cymbopogan martini, were the next preferred plant species during summer season. Pinus wallichiana, Vibernum foetens and Eleagnus orientalis were preferred during winter season. Fragaria nubicola was the least eaten plant species during summer and winter with smallest relative importance value.

During summer diet breadth of Vibernum foetens was greater (23.52), while during winter that of Pyrus pashia was greater (16.02) as compared to other plant species. Fruit of Aesculus indica was also consumed. Fruits were found from the fecal collection sites of grey langur (7-8 eight fruits at each site). This information is supported by Vuorela (2005) who reported that Aesculus indica constituted about $23.35 \%$ of langur diet. They were seen feeding upon its bark and leaf buds as well. This is also supported by Mir et al. (2015) who reported that Langur diet constituted $17.1 \%$ fruits in Dachigam National Park, Kashmir, India. The seeds of Aesculus indica are known to have high nutritional value containing good amounts of various mineral elements (Majeed et al., 2010).

Ensuring the survival and population growth of Grey langur, Park management staff must ensure the continued availability of the preferred plant species in the habitat of this species.

\section{Statement of conflict of interest}

The authors declare no conflict of interest.

\section{REFERENCES}

Ahmed, K.B., Awan, M.S. and Anwar, M., 1999. Status of major wildlife species in Moji Game Reserve, Leepa Valley Azad Kashmir. Proc. Pak. Congr. Zool., 19: 173-182.

Alipayo, D., Valdez, R., Holechek, J.L. and Cardenas, M., 1992. Evaluation of microhistological analysis for determining ruminant diet botanical composition. J. Range Manage., 45: 148-152. https://doi.org/10.2307/4002773

Altmann, J., 1980. Baboon mothers and infants. Harvard University Press, Cambridge.

Baig, K.J., 2004. Baseline data for zoological and wildlife studies in Machiara National Park. Protected Areas Management Project (PAMP). Muzaffarabad, AJK, pp. 78.

Bhattacharya, T., Bashir, T. Poudyal, K., Sathyakumar, S. and Saha, G.K., 2012. Distribution, occupancy and activity patterns of goral (Nemorhaedus goral) and serow (Capricornis thar) in Khangchendzonga Biosphere Reserve, Sikkim, India. Mammal Study, 37: 173-181. https://doi.org/10.3106/041.037.0302

Brandon, J.D., 2004. A taxonomic revision of the langurs and leaf monkeys (Primates: Colobinae) of
South Asia. Zoos' Print J., 19: 1552-1594. https:// doi.org/10.11609/JoTT.ZPJ.971.1552-94

Chapman, C.A., 1988. Pattern of foraging and range use by three species of neotropical primates. Primates, 29: 177-194. https://doi.org/10.1007/BF02381121

Chen, J., Shang, S. Wu, X. Yan, J. Zhong, H. Zhang, H. Sha, W. Zhu, W. and Zhang, H., 2018. The microbial community in the feces of cape oryx (Oryx gazella) as determined by highthroughput illumina sequencing technology. Pakistan J. Zool., 50: 1601-1610.

Dar, N.A., 2006. Wildlife of Azad Kashmir. Al-Sheikh Press, Muzaffarabad, AJK, pp. 69.

Dusi, J.L., 1949. Methods for the determination of food habits by plant micro-techniques and histology and their application to cottontail rabbit food habits. J. Wildl. Manage., 13: 295-298. https://doi. org/10.2307/3795871

Edwards, P.B., 1991. Seasonal variation in the dung of African grazing mammals and its consequences for coprophagous insects. Funct. Ecol., 5: 617-628. https://doi.org/10.2307/2389480

Fjellstad, J.I. and Steinheim, G., 1996. Diet and habitat use of Greater Indian one horned rhinoceros (Rhinoceros unicornis) and Asian elephant (Elephas maximus) during the day season in Babai valley, Royal Bordia National Park, Nepal. M.Sc. thesis, NLH Agriculture University of Norway, pp. 48.

GoAJK, 2005. Revised management plan Machiara National Park. Department of Wildlife and Fisheries, Government of Azad Jammu and Kashmir, Muzaffarabad, pp. 138.

Groves, C., 2001. Primate taxonomy. Smithsonian Institution Press, pp. 350.

Hassan, S.A. 2004. Compilation of Baseline data for ornithological studies in Machiara National Park. AJK. PAMP.

Hilton, T.C., 2000. IUCN Red list of threatened species. International Union for Conservation of Nature, Gland, Switzerland and Cambridge, UK.

Holechek, J.L., Vavra, M. and Pieper, R.D., 1982. Botanical composition determination of range herbivore diets. J. Range Manage., 35: 309-315. https://doi.org/10.2307/3898308

Jnawali, S.R., 1995. Population ecology of greater onehorned rhinoceros (Rhinoceros unicornis) with particular emphasis on habitat preference, food ecology and ranging behavior of a reintroduced population in Royal Bardia National Park in lowland Nepal. Ph.D. thesis Agricultural University of Norway, pp. 129.

IUCN, 2012. IUCN red list of threatened species. 
International Union for Conservation of Nature, Gland, Switzerland and Cambridge, UK.

Lode, T., 1996. Polecat predation on frogs and toads at breeding sites in western France. Ethol. Ecol. Evol., 8: 115-124. https://doi.org/10.1080/08927014.1996 .9522922

Majeed, M., Khan, M.A., Bashir, A. and Hussain, A., 2010. Nutritional value and oil content of Indian Horse-Chestnut seed. Glob. J. Sci. Front. Res., 10: 17-19.

Matrai, K., Altbacker, V. and Hahn, I., 1998. Seasonal diet of rabbits and their browsing effect on juniper in Bugac Juniper Forest (Hungary). Acta Theriol., 43: 107-112. https://doi.org/10.4098/AT.arch.98-8

Mir, Z.R., Noor, A. Habib, B. and Veeraswami, G.G., 2015. Seasonal population density and winter survival strategies of endangered Kashmir gray langur (Semnopithecus ajax) in Dachigam National Park, Kashmir, India. Springer Plus, 4: 562. https:// doi.org/10.1186/s40064-015-1366-Z

Minhas, R.A., Ahmed, K.B., Awan, M.S. and Dar, N.I., 2010. Habitat utilization and feeding biology of Himalayan grey langurs (Semnopithecus entellus ajax) in Machiara National Park, Azad Jammu and Kashmir. Pakistan Zool. Res., 31: 177-188.

Minhas, R.A., Ahmed, K.B., Awan, M.S., Dar, N.I., Zaman, Q. and Ali, H., 2012. Distribution pattern and population status of the Himalayan grey langur (Semnopithecus ajax) in Machiara National Park, Azad Jammu and Kashmir. Pakistan J. Zool., 44: 869-877.

Negi, S.S., 1983. Himalayan wildlife habitat and conservation. Indus Publishing Company, New Delhi, India.

Nowak, R.M., 1999. Walker's mammals of the world. The Johns Hopkins Press, Baltimore, pp. 227-240.

Overdorff, D.J., 1996. Ecological correlates to activity and habitat use of two prosimian primates Eulemur rubriventer and Eulemur fulvus fufus in Madagascar. Am. J. Primatol., 40: 327-342. https://doi.org/10.1002/(SICI)10982345(1996)40:4<327::AID-AJP3>3.0.CO;2-\#

Prins, H.H.T., Deboer, W.F., Oeveren, H.V., Correia, A., Mafuca, J. and Olff, H., 2006. Co-existence and niche segregation of three small bovid species in the
Southern Mozambique. Afri. J. Ecol., 44: 186-198. https://doi.org/10.1111/j.1365-2028.2006.00619.x

Qamar, Q.Z. 1996. Status of major wildlife species and their management in Ghamot National Park Neelum Valley, District Muzaffarabad. M.Sc. thesis, Department of Zoology, University of AJK, Muzaffarabad.

Qamar, Q.Z. and Minhas, R.A., 2006. Important medicinal plants and their local uses in Machiara National Park, Muzaffarabad. Al-Sheikh Printing Press, Muzaffarabad, pp. 61.

Rajpurohit, D.S., 2005. Study of the dominance hierarchy and its role in social organization in Hanuman langur, Semnopithecus entellus entellus. Republished Ph.D. thesis, Jai Narain Vyas University Jodhpur, Rajasthan, India.

Remis, M.J., 1997. Western lowland gorillas vores: Use of variable resources. Am. J. Primatol., 43: 87-109. https://doi.org/10.1002/(SICI)10982345(1997)43:2<87::AID-AJP1>3.0.CO;2-T

Robert, T.J., 1997. The mammals of Pakistan, Revised ed. Oxford University Press, Karachi, pp. 525.

Shrestha, R. and Wegge, P., 2006. Determining the composition of herbivore diets in the transHimalayan rangeland: A comparison of field methods. Rangeland Ecol. Manage., 59: 512-518. https://doi.org/10.2111/06-022R2.1

Smith, A.D. and Shandruk, L.J., 1979. Comparison of fecal, rumen and utilization methods for ascertaining pronghorn diets. J. R. microscop. Soc., 32: $275-279$.

Sparks, D.R. and Malechek, J.C., 1968. Estimating percentage dry weight in diets using a microscopic technique. J. Range Manage., 21: 264-265. https:// doi.org/10.2307/3895829

Tritsch, M.F., 2001. Wildlife of India. Thomson Press Ltd., India, pp. 102.

Vuorela, S., 2005. Analysis, isolation, and bioactivities of rapeseed phenolics (dissertation). EKT series 1343. University of Helsinki. Department of Applied Chemistry and Microbiology. 105 pp.

Wiens, J.A. and Milne, B.T., 1989. Scaling of 'landscapes' in landscape ecology, or, landscape ecology from a beetle's perspective. Landsc. Ecol., 3: $87-96$. 